\title{
PENINGKATAN LITERASI ANAK USIA 4-6 TAHUN MELALUI BAHAN AJAR MEMBACA, MENULIS, DAN BERHITUNG UNTUK GURU TK DI KECAMATAN CINERE DAN LIMO DEPOK
}

\author{
Ana Widyastuti \\ Fakultas Bahasa dan SeniUniversitas Indraprasta PGRI \\ anawidyastuti35@gmail.com
}

\begin{abstract}
Abstrak
Keberhasilan pendidikan anak usia dini terletak pada pendidik atau guru. Pendidik atau guru harus mampu membimbing, membantu dan mengarahkan anak didiknya untuk meningkatkan literasi. Salah satu yang hendak dicapai dalam mengoptimlkan kemampuan anak dini atau usia TK (4-6 tahun) adalah kemampuan membaca, menulis dan berhitung (CALISTUNG). Banyaknya keluhan dari orangtua murid alumni TK yang mengatakan bahwa anak yang lulus dari sekolah Taman Kanak-Kanak (TK) belum mampu Calistung. Kemampuan Calistung anak masih kurang optimal dikarenakan para guru TK khususnya guru TK di kecamatan Cinere dan Limo Depok masih belum mampu membuat bahan ajar yang tepat untuk anak usia 4-6 tahun. Metode pelaksanaan kegiatan ini adalah pelatihan intensif pada guru Taman Kanak-Kanak (TK) di kecamatan Cinere dan Limo Depok yaitu membuat bahan ajar berupa Lembar Kerja Siswa (LKS) untuk anak usia 4- 6 tahun dengan materi Calistung dan unjuk kerja hasil pembuatan Lembar Kerja Anak yang dijadikan buku Calistung di akhir pelatihan. Setelah melalui tahap revisi dan perbaikan, LKS tersebut dijadikan buku, untuk selanjutnya diajukan ke penerbit. Dalam praktik pelatihan pembuatan bahan ajar LKS Calistung, maka hasil dan pembahasannya adalah:(a) Kelompok guru yang membuat LKS Membaca, mulai memahami bagaimana membuat bahan ajar (LKS) dengan karakter yang baik, antara lain LKS harus variatif, mendalam, menarik, mudah, sesuai minat dan kebutuhan anak, dan sebagainya, sehingga masih diperlukan revisi kembali (b) Kelompok guru yang membuat LKS Menulis, sudah cukup memahami terlihat dari cara mereka menulis LKS seperti tahapan awal menulis yakni menebalkan garis horizontal, menebalkan garis vertikal, menebalkan garis putus-putus, menulis angka dengan menebalkan garis putusputus, menulis huruf dengan menebalkan garis putus-putus, sampai menulis huruf tegak bersambung dengan menebalkan huruf-hurufnya.(c) Kelompok guru yang membuat LKS Berhitung cukup terampil, tampakdari prosesnya sudah melalui tiga tahapanyaitu penguasaan konsep, masa transisi, dan lambang. Namun dalam prinsip yang harus diperhatikan dalam berhitung ialah permainan berhitung diberikan secara bertahap, diawali dengan (1) menghitung benda-benda atau peristiwa pengalaman konkrit yang dialami melalui pengamatan terhadap alam sekitarnya, (2) Pengetahuan dan keterampilan pada permainan berhitung diberikan secara bertahap menurut tingkat kesukarannya, misalnya dari konkrit ke abstrak, mudah ke sukar, dan dari sederhana ke yang lebih kompleks, (3) Permainan berhitung akan berhasil jika anak-anak diberi kesempatan berpartisipasi dan dirangsang untuk menyelesaikan masalah-masalahnya sendiri, (4) Permainan berhitung membutuhkan suasana yang menyenangkan dan rasa aman serta kebebasan bagi anak. Untuk itu diperlukan alat peraga/media yang sesuai dengan benda sebenarnya (tiruan), menarik dan bervariasi, mudah digunakan dan tidak membahayakan, (5) Bahasa yang digunakan dalam pengenalan konsep berhitung seyogyanya bahasa yang sederhana dan jika memungkinkan mengambil contoh yang terdapat di lingkungan sekitar anak, (6) Dalam permainan berhitung anak dapat dikelompokkan sesuai tahap penguasaannya yaitu tahap konsep, masa transisi dan lambang, terkadang masih mengacak, namun proses pembuatan LKS mulai sesuai urutan yang benar.
\end{abstract}

Kata kunci : Literasi,bahan ajar, anak usia 4-6 tahun, calistung 
Ana Widyastuti. et al. Peningkatan Literasi Anak Usia 4-6 Tahun Melalui Bahan Ajar Membaca, Menulis, dan ...

\section{PENDAHULUAN}

Anak usia dini merupakan masa emas (golden ages) perkembangan. Disebut masa emas karena pada masa itu terjadi lonjakan luar biasa dan menurun setelah masa emas telah terlampaui. Masa tepat untuk melejitkan seluruh kemampuan anak usia dini.

Pendidikan anak usia dini adalah suatu upaya pembinaan yang ditujukan kepada anak sejak lahir (0 tahun) sampai usia 6 (enam) tahun yang dilakukan melalui rangsangan pendidikan untuk membantu pertumbuhan dan perkembangan jasmani dan rohani agar anak memiliki kesiapan dalam memasuki pendidikan lebih lanjut. Hal ini mengamanatkan dengan tegas perlunya penanganan pendidikan anak usia dini.

Satuan Pendidikan anak usia dini (PAUD) adalah salah satu bentuk satuan pendidikan bagi anak usia dini termasuk Pendidikan TK yaitu anak usia 4-6 tahun yang terbagi dalam dua kelompok belajar berdasarkan usia yaitu kelompok A untuk anak 4-5 tahun, dan kelompok B untuk anak didik usia 5-6 tahun, Literasi adalah kemampuan membaca dan menulis. Literasi sebagai salah satu indikator pencapaian perkembangan yang meliputi kemampuan membaca, menulis ditambah dengan berhitung yang disingkat dengan Calistung merupakan materi dasar anak usia TK (4-6 tahun) sebagai pembekalan ke jenjang Sekolah Dasar (SD). Para guru TK sekota Depok belum mampu mengoptimalkan membaca, menulis, berhitung (Calistung) pada anak. Keberhasilan pendidikan anak usia dini terletak pada pendidik atau guru. Pendidik atau guru harus mempu membimbing, membantu dan mengarahkan anak didiknya. Salah satu yang hendak dicapai dalam mengoptimlkan kemampuan anak usia TK atau 4-6 tahun adalah kemampuan membaca, menulis dan berhitung (CALISTUNG). Banyaknya keluhan dari orangtua murid alumni TK yang mengatakan bahwa anak yang lulus dari sekolah Taman Kanak-Kanak (TK) belum mampu Calistung. Kemampuan Calistung anak masih kurang optimal dikarenakan para guru TK khususnya guru TK sekota Depok masih belum mampu membuat bahan ajar yang tepat untuk anak usia 4-6 tahun.

Kondisi ekonomi yang rendah menyebabkan keluarga tidak mampu menyediakan makanan bergizi bagi anggota keluarga. Bila terjadi dalam waktu yang lama akan berdampak pada kekurangan gizi dan yang paling rentan mengalaminya adalah kelompok anak balita dan ibu hamil. Mengalaminya adalah kelompok anak balita dan ibu hamil.

Literasi yang dalam bahasa Inggrisnya literacy berasal dari bahasa Latin littera (huruf) yang pengertiannya melibatkan penguasaan sistem-sistem tulisan dan konvensi-konvensi yang menyertainya. Namun demikian, literasi utamanya berhubungan dengan bahasa dan bagaimana bahasa itu digunakan. Adapun sistem bahasa tulis itu sifatnya sekunder. Manakala berbicara mengenai bahasa, tentunya tidak lepas dari pembicaraan mengenai budaya karena bahasa itu sendiri merupakan bagian dari budaya. Sehingga, pendefinisian istilah literasi tentunya harus mencakup unsur yang melingkupi bahasa itu sendiri, yakni situasi sosial budayanya.

Istilah Literasi (Literacy) menurut Ahmad Susanto, sudah berkembang cukup lama. Makna literasi mengalami perubahan dari waktu ke waktu. Sehingga didefinisikan dengan cakupan yang sangat luas. Nloome dalam Suyanto (2005:35) mengatakan bahwa literasi itu sifatnya dinamis dan relatif sehingga hanya dari suatu negara atau budaya ke negara atau budaya lain. Sementara itu menurut Graff dan Gee, literasi bukan suatu keterampilan atau fenomena tunggal. Literasi merupakan konsep yang tidak pernah berakhir. Blustein mengemukakan dengan literasi mencakup perpaduan mendengar, berbicara, dan berpikir kritis dengan membaca dan menulis. Membaca dan menulis jika digabungkan dengan mendengar, melihat, berbicara, dan berpikir kritis merupakan aspek yang sangat bernilai untuk kehidupan modern. Literasi memingkinkan seseorang berinteraksi dengan berbagai sumber informasi yang kompleks. ${ }^{1}$

Berkenaan dengan ini, Kern mendefinisikan istilah literasi secara komprehensif sebagai berikut:

Literacy is the use of socially-, and historically-, and culturallysituated practices of creating and interpreting meaning through texts. It entails at least a tacit awareness of

\footnotetext{
1 Ahmad Susanto, Bimbingan \& Konseling di Taman Kanak-Kanak (Jakarta: Kencana, 2017) ha1.149.
} 
Ana Widyastuti. et al. Peningkatan Literasi Anak Usia 4-6 Tahun Melalui Bahan Ajar Membaca, Menulis, dan ...

the relationships between textual conventions and their context of use and, ideally, the ability to reflect critically on those relationships. Because it is purpose-sensitive, literacy is dynamic - not static - and variable across and within discourse communities and cultures. It draws on a wide range of cognitive abilities, on knowledge of written and spoken language, on knowledge of genres, and on cultural knowledge. ${ }^{2}$

(Literasi adalah penggunaan praktikpraktik situasi sosial, dan historis, serta kultural dalam menciptakan dan menginterpretasikan makna melalui teks. Literasi memerlukan setidaknya sebuah kepekaan yang tak terucap tentang hubunganhubungan antara konvensi-konvensi tekstual dan konteks penggunaanya serta idealnya kemampuan untuk berefleksi secara kritis tentang hubungan-hubungan itu. Karena peka dengan maksud/ tujuan, literasi itu bersifat dinamis - tidak statis - dan dapat bervariasi di antara dan di dalam komunitas dan kultur diskursus/ wacana. Literasi memerlukan serangkaian kemampuan kognitif, pengetahuan bahasa tulis dan lisan, pengetahuan tentang genre, dan pengetahuan kultural).

Dari pernyataan di atas dapat diketahui bahwa literasi memerlukan kemampuan yang kompleks. Adapun pengetahuan tentang genre adalah pengetahuan tentang jenis-jenis teks yang berlaku/ digunakan dalam komunitas wacana misalnya, teks naratif, eksposisi, deskripsi dan lain-lain. Terdapat tujuh unsur yang membentuk definisi tersebut, yaitu berkenaan dengan interpretasi, kolaborasi, konvensi, pengetahuan kultural, pemecahan masalah, refleksi, dan penggunaan bahasa. Ketujuh hal tersebut merupakan prinsip-prinsip dari literasi.

Menurut UNESCO yang dikutip oleh Nasution, memasukkan enam kategori kelangsungan hidup kemampuan literasi abad 21 yang terdiri dari:

1) Basic Literacy, kadang-kadang disebut Literasi Fungsional (Functional Literacy), merupakan kemampuan dasar literasi atau sistem belajar konvensional seperti

\footnotetext{
2 Kern, Richard., Literacy and Language Teaching. ( Oxford: Oxford University Press, 2000)
}

bagaimana membaca, menulis, dan melakukan perhitungan numerik dan mengoperasikan sehingga setiap individu dapat berfungsi dan memperoleh kesempatan untuk berpartisipasi di masyarakat, di rumah, di kantor maupun sekolah.

2) Computer literacy, merupakan seperangkat keterampilan, sikap dan pengetahuan yang diperlukan untuk memahami dan mengoperasikan fungsi dasar teknologi informasi dan komunikasi, termasuk perangkat dan alatalat seperti komputer pribadi (PC), laptop, ponsel, iPod, BlackBerry, dan sebagainya, literasi komputer biasanya dibagi menjadi hardware dan software literasi.

3) Media Literacy, merupakan seperangkat keterampilan, sikap dan pengetahuan yang diperlukan untuk memahami dan memanfaatkan berbagai jenis media dan format di mana informasi di komunikasikan dari pengirim ke penerima, seperti gambar, suara, dan video, dan apakah sebagai transaksi antara individu, atau sebagai transaksi massal antara pengirim tunggal dan banyak penerima, atau, sebaliknya.

4) Distance Learning dan E-Learning adalah istilah yang merujuk pada modalitas pendidikan dan pelatihan yang menggunakan jaringan telekomunikasi, khususnya world wide web dan internet, sebagai ruang kelas virtual bukan ruang kelas fisik. Dalam distance learning dan e-learning, baik guru dan siswa berinteraksi secara online, sehingga siswa dapat menyelesaikan penelitian dan tugas dari rumah, atau di mana saja di mana mereka dapat memperoleh akses ke komputer dan saluran telepon.

5) Cultural Literacy. Merupakan literasi budaya yang berarti pengetahuan, dan pemahaman, tentang bagaimana suatu negara, agama, sebuah kelompok etnis atau suatu suku, keyakinan, simbol, perayaan, dan cara komunikasi tradisional, penciptaan, penyimpanan, penanganan, komunikasi, pelestarian dan pengarsipan data, informasi dan pengetahuan, menggunakan teknologi. Sebuah elemen penting dari pemahaman literasi informasi adalah kesadaran tentang bagaimana faktor budaya 
Ana Widyastuti. et al. Peningkatan Literasi Anak Usia 4-6 Tahun Melalui Bahan Ajar Membaca, Menulis, dan ...

berdampak secara positif maupun negatif dalam hal penggunaan informasi modern dan teknologi komunikasi .

6) Information literacy, erat kaitannya dengan pembelajaran untuk belajar, dan berpikir kritis, yang menjadi tujuan pendidikan formal, tapi sering tidak terintegrasi ke dalam kurikulum, silabus dan rencana pelajaran, kadang-kadang dibeberapa negara lebih sering menggunkan istilah information competencies atau information fluency atau bahkan istilah lain. Literasi media merupakan bagian dari literasi informasi yang seiring dengan perkembangan media agar mampu mempunyai kemampuan dan sikap terhadap penggunaan media. ${ }^{3}$

Berdasarkan pengertian literasi dari beberapa ahli di atas, menunjukkan bahwa pengertian dan penggunaan konsep literasi merupakan suatu kontinum yang dinamis, yakni mulai dari kemampuan membaca, kemudian membaca dan menulis, berpikir kritis dan berbahasa lisan yang bergerak mengikuti zaman dan dimanfaatkan untuk belajar sepanjang hayat baik di rumah, di tempat kerja, maupun dalam masyarakat.

Kemendikbud menjelaskan bahwa satuan PAUD untuk kelompok anak usia 4-6 tahun dengan lama belajar paling sedikit 900 menit per minggu. ${ }^{4}$

Selain itu dalam Undang-Undang Nomor 20 Tahun 2003 tentang Sistem Pendidikan Nasional Bab I Pasal 1 butir 14 menyatakan bahwa PAUD merupakan upaya pembinaan yang ditujukan kepada anak sejak lahir sampai dengan usia 6 tahun yang dilakukan melalui rangsangan pendidikan. $^{5}$

Sedangkan Anak usia dini menurut NAEYC (National Association for The Education of Young Children), adalah anak yang berusia antara 0 sampai 8

\footnotetext{
3 Nasution, Laila Hadri, Analisis Literasi Informasi Pengguna Perpustakaan Universitas Sumatera Utara. (Tesis). (Bogor: Institut Pertanian Bogor, 2013), hlm.12-13.

4 Kemendikbud. Peraturan Menteri Pendidikan dan Kebudayaan no. 137 Tahun 2014 Tentang Standar Pendidikan Anak Usia Dini. (Jakarta: Direktorat Jenderal Pendidikan dan Kebudayaan, 2014), hlm 25

5 Kemendikbud. Peraturan Menteri Pendidikan dan Kebudayaan no. 137 Tahun 2014 Tentang Standar Pendidikan Anak Usia Dini. (Jakarta: Direktorat Jenderal Pendidikan dan Kebudayaan, 2014), hlm 25
}

tahun yang mendapatkan layanan pendidikan di taman penitipan anak, penitipan anak dalam keluarga (family child care home), pendidikan prasekolah baik negeri maupun swasta, taman kanakkanak (TK) dan sekolah dasar (SD). ${ }^{6}$

Berdasarkan deskripsi di atas, maka hal ini menunjukkan bahwa anak usia 4-6 tahun merupakan satuan PAUD usia TK anak prasekolah yang membutuhkan rangsangan pendidikan.

\section{a. Bahan Ajar}

Sebagaimana

Mulyasa

mengemukakan bahwa bahan ajar merupakan salah satu bagian dari sumber ajar yang dapat diartikan sesuatu yang mengandung pesan pembelajaran, baik yang bersifat khusus maupun yang bersifat umum yang dapat dimanfaatkan untuk kepentingan pembelajaran. ${ }^{7}$

Menurut Dick, Carey, dan Carey menambahkan bahwa instructional material contain the conten either written, mediated, or facilitated by an instructor that a student as use to achieve the objective also include information thet the learners will use to guide the progress. ${ }^{8}$

Berdasarkan ungkapan Dick, Carey, dan Carey dapat diketahui bahwa bahan ajar berisi konten yang perlu dipelajari oleh siswa baik berbentuk cetak atau yang difasilitasi oleh pengajar untuk mencapai tujuan tertentu.

Bahan ajar adalah seperangkat sarana atau alat pembelajaran yang berisikan materi pembelajaran, metode, batasanbatasan, dan cara mengevaluasi yang didesain secara sistematis dan menarik dalam rangka mencapai tujuan yang diharapkan, yaitu mencapai kompetensi dan

\footnotetext{
6 Nurani Sujiono, Yuliani, Konsep Dasar Pendidikan Anak Usia Dini. Jakarta: PT Indeks,2009), hlm 20

${ }^{7}$ Mulyasa, Kurikulum Berbasis Kompetensi. (Bandung: PT Remaja Rosdakarya, 2006), hal. 96

8

Dick Walter, Carey Lou., and Carey, J.O, The Systematic Design of Instruction. Upper Saddler River, (New Jersey: Pearson Education, Inc, 2009), hlm. 15
} 
Ana Widyastuti. et al. Peningkatan Literasi Anak Usia 4-6 Tahun Melalui Bahan Ajar Membaca, Menulis, dan ...

\begin{abstract}
subkompetensi dengan segala kompleksitasnya. ${ }^{9}$

Pengertian ini menggambarkan bahwa bahan ajar hendaknya dirancang dan ditulis sesuai dengan kaidah pembelajaran, yakni disesuaikan materi pembelajaran, disusun berdasarkan atas kebutuhan pembelajaran, terdapat bahan evaluasi, serta bahan ajar tersebut menarik untuk dipelajari oleh siswa.
\end{abstract}

Menurut BSNP tentang buku ajar adalah:

"Sebuah buku ajar yang baik adalah buku yang minimal megacu pada sasaran yang akan dicapai peserta didik, dalam hal ini adalah standart kompetensi dan kompetensi dasar, artinya buku/bahan ajar harus memperhatikan komponen kelayakan isi; Berisi informasi, pesan dan pengetahuan yang dituangkan dalam bentuk tertulis yang dapat dikomunikasikan kepada pembaca secara logis dan mudah diterima sesuai dengan tahap kognitif siswa, artinya sebuah buku/bahan ajar harus memperhatikan komponen kebahasaannya; Berisi konsep-konsep yang disajikan secara menarik, interaktif dan mampu mendorong terjadinya proses berfikir kritis, kreatif, inovatif dan kedalaman berfikir serta metakognisi dan evaluasi diri." 10

Sebuah buku/bahan ajar harus memperhatikan komponen penyajian, yang berisi teknik penyajian dan pendukung penyajian materi; Secara fisik tersaji dalam wujud tampilan yang menarik dan menggambarkan ciri khas buku pelajaran. Dengan perkataan lain buku/bahan ajar harus memenuhi syarat kegrafikaan.

Jenis bahan ajar dibedakan atas beberapa kriteria pengelompokan. Menurut Koesnandar, jenis bahan ajar berdasarkan subjeknya terdiri dari dua jenis antara lain: (a) bahan ajar yang sengaja dirancang untuk belajar, seperti buku, handouts, LKS dan

\footnotetext{
9 Ika Lestari, Pengembangan Bahan Ajar Berbasis Kompetensi. (Padang: Akademia Permata, 2013), hlm.1. 10 BSNP, Naskah Akademik Instrumen Penilaian Buku Teks Pelajaran
Pendidikan Dasar dan Menengah Tahap II. (Jakarta: BSNP, 2006), hlm. 15
}

modul; (b) bahan ajar yang tidak dirancang namun dapat dimanfaatkan untuk belajar, misalnya kliping, koran, film, iklan atau berita. Koesnandar juga menyatakan bahwa jika ditinjau dari fungsinya, maka bahan ajar yang dirancang terdiri atas tiga kelompok yaitu bahan presentasi, bahan referensi, dan bahan belajar mandiri. $^{11}$

Berdasarkan teknologi yang digunakan, Direktorat Pembinaan Sekolah Menengah Atas mengelompokkan bahan ajar menjadi empat kategori, yaitu bahan ajar cetak (printed) antara lain handout, buku, modul, lembar kegiatan siswa, brosur, leaflet, wallchart, foto/gambar, dan model/maket. Bahan ajar dengar (audio) antara lain kaset, radio, piringan hitam, dan compact disk audio. Bahan ajar pandang dengar ( audio visual) seperti video compact disk, dan film. Bahan ajar multimedia interaktif (interactive teaching material) seperti CAI (ComputerAssisted Instruction), compact disk (CD) multimedia pembelajaran interaktif dan bahan ajar berbasis web (web based learning material). ${ }^{12}$

M. Atwi Suparman menyatakan bahwa bahan ajar memiliki ciri-ciri sebagai berikut.

1) Self instructional, yang berarti bahan ajar dapat dipelajari sendiri oleh siswa karena disusun untuk maksud tersebut.

2) Self explanatory power, yaitu bahan ajar mampu menjelaskan sendiri karena menggunakan bahasa yang sederhana, isinya runtut, dan tersusun secara sitematik.

3) Self paced learning, yaitu siswa dapat mempelajari bahan ajar dengan kecepatan yang sesuai dengan dirinya tanpa perlu menunggu siswa lain yang lebih lambat atau merasa ketinggalan dari siswa yang lebih cepat.

4) Self contained, yaitu bahan ajar itu lengkap dengan sendirinya sehingga siswa tidak perlu tergantung dengan bahan ajar lainnya, kecuali bila bermaksud untuk memperkaya dan memperdalam pengetahuannya.

5) Individualized learning materials, yaitu bahan ajar didesain sesuai dengan kemampuan dan karakteristik siswa yang sedang mempelajarinya.

\footnotetext{
11 Koesnandar. (2008).Pengembangan Bahan Ajar Berbasis Web. [Online] tersedia di http://www.teknologipendidikan .net diakses tanggal 24 September 2017.

${ }^{12}$ Direktorat Pembinaan Sekolah Menengah Atas., Panduan Pengembangan Bahan Ajar(Jakarta: Departemen Pendidikan Nasional, 2008), hlm. 11
} 
Ana Widyastuti. et al. Peningkatan Literasi Anak Usia 4-6 Tahun Melalui Bahan Ajar Membaca, Menulis, dan ...

6) Flexible and mobile learning materials, yaitu bahan ajar yang dapat dipelajari siswa kapan saja, di mana saja, dalam keadaan diam atau bergerak.

7) Communicative and interactive learning materials, yaitu bahan ajar didesain sesuai dengan prinsip komunikatif yang efektif dan melibatkan proses interaksi dengan siswa yang sedang mempelajarinya.

8) Multimedia, computer based materials, yaitu bahan ajar yang didesain berbasiskan multimedia termasuk pendayagunaan computer secara optimal bila siswa mempunyai akses terhadapnya.

9) Supported by tutorials, and study group, yaitu bahan ajar masih mungkin membutuhkan dukungan tutorial dan kelompok belajar. ${ }^{13}$

Kehadiran bahan ajar selain membantu siswa dalam pembelajaran juga sangat membantu guru. Dengan adanya bahan ajar guru lebih leluasa mengembangkan materi pelajaran. Berdasarkan kedua pendapat di atas mengenai karakteristik bahan ajar, peneliti mensintesiskan bahwa bahan ajar haruslah berisi materi yang memadai, bervariasi, mendalam, mudah dibaca, serta sesuai minat dan kebutuhan siswa. Selain itu, bahan ajar haruslah berisi materi yang disusun secara sistematis dan bertahap. Materi disajikan dengan metode dan sarana yang mampu menstimulasi siswa untuk tertarik membaca. Terakhir, bahan ajar haruslah berisi alat evaluasi yang memungkinkan siswa mampu mengetahui kompetensi yang telah dicapainya.

\section{b. Membaca, Menulis, dan Berhitung}

Calistung

$$
{ }^{14} \text { Alya Qonita mengatakan bahwa }
$$

merupakanakronimdaribelajarmembaca,belaja $\mathrm{r}$ menulisdan belajar menghitung, penggabungan kalimatCalistung karena program pembelajaranyang diterapkanuntukanakdidikdalamprosesbelajar, berikut pengertiansecara terinci:

a. Baca, membaca, artinya:

1) Melihat sertamemahami isi dari apa yang tertulis dengan melisankan atau

\footnotetext{
13 M Atwi Suparman, Panduan Para Pengajar dan Inovator Pendidikan: Desain Instruksional Modern.(Jakarta: Erlangga, 2012), hlm. 284.

14 Alya Qonita, Kamus Bahasa Indonesia untuk Pendidikan Dasar.( Jakarta:PT Indah Jaya Adipratama, 2009), hlm. 45.
}

hanyadalam hati.

2) Melisankan atau melafalkan apayangtertulis.

3) Mengucapkan.

4) Mengetahui , meramalkan.

5) Memperhitungkan, memahami

Menurut Marhnis Yamin, membaca adalah suatucara untuk mendapatkan informasi yang disampaikan secara verbal dan merupakan hasil ramuan pendapat, gagasan, teori-teori, dan menjadi pengetahuan siswa, kemudian pengetahuan tersebut dapat diserap dalam berpikir, menganalisis, bertindak dan dalam pengambilan keputusan membaca membutuhkan keterampilan, kebiasaan dan konsentrasi, penguasaan kata dan kecepatan membaca. ${ }^{15}$

b. Tulis, menulis, artinya:

1) Membuat huruf (angka) dengan pena (pensil, kapur,dsb)

2) Melahirkan pikiranatau perasaan (seperti mengarang, membuat surat) dengan tulisan.

3) Membatik (kain).

c. Hitung, menghitung, artinya:

Membilangkan (menjumlahkan, mengurangi, membagi dan memperbanyak).

Dalam system pendidikan nasional (Sisdiknas) Undang-Undang No.20 tahun 2003. Termuat dalam bab III pasal 4 ayat 5 mengenai "pendidikan diselenggarakan dengan mengembangkan budaya membaca, menulis, dan menghitung bagi segenap warga masyarakat MortimerJ. Adler dan Charles Van Doren, ,(Ed.), "Irene Pontoh dkk": mengemukakan bahwa:

"Tahap pertama dalam belajar membaca disebut "kesiapan membaca dari sejak lahir sampai sekitar usia 6-7 tahun, kesiapan membaca meliputi berbagai kesiapan belajar diantaranya kesiapan fisik meliputi penglihatan dan pendengaran yang baik, kesiapan intelektual meliputi persepsi visual anak bias menyerap dan mengingat kata-kata dan huruf, kesiapan bahasa meliputi kemampuan berbicara dengan jelas, kesiapan kepribadian meliputi kemampuan bekerja sama dengan anak lain.Yang paling penting diperhatikan usaha percepatan biasanya justru

\footnotetext{
${ }^{15}$ Yamin Marhnis, Kiat Pembelajaran Siswa. (Jakarta: Putra Grafika, 2009), 106.
} 
Ana Widyastuti. et al. Peningkatan Literasi Anak Usia 4-6 Tahun Melalui Bahan Ajar Membaca, Menulis, dan ...

merusak mental, anak belum siap membaca menjadi frustasi jika dipaksa untuk belajar dan perasaan ini mungkin akan terbawa ke jenjang pendidikan selanjutnya"16

Soegeng Santoso mengemukakan bahwa pelajaran membaca, menulis dan berhitung sangat menentukan keberhasilan anak untuk belajar pada jenjang pendidikan selanjutnya ketiga mata pelajaran ini sering disebut 3R yaitu sengkatan dari Read,Write dan Arithmatic. Ketiganya harus diefektifkan pelaksanaannya ketika di sekolah dasar. Sebab pelajaran itu merupakan dasar bagi seseorang untuk mengenyam pendidikan di kemudian hari. ${ }^{17}$

Kesiapan membaca menulis, dan berhitung, sudah dapat dimulai sejak anak pra sekolah. Dengan memiliki kesiapan membaca, anak dapat meningkatkan kemampuannya dalam menggunakan berbagai kosa kata. kesiapan menulis berawal dari ide/gagaasan yang muncul, yang akan dituliskan di atas kertas. Dalam melatih anak kesiapan menulis, pendidik perlu menjelaskan secara eksplisit bahwa jika ada tulisan yang salah, anak memiliki kesempatan untuk menghapus atau merubahnya. Kesiapan menulis adapat emmbantu anak untuk menulis dengan tujuan yang jelas, menulis kalimat yang benar, menggunakan tanda baca yang tepat, menulis dengan jelas dan relatif rapi, merangkai dengan baik serat memilih kata-kata yang tepat. Dalam kesiapan berhitung, anak perlu dijelaskan bahwa matematika sangat penting dalam kehidupan, dan kita membutuhkan keterampilan ini dalam kehidupan, dan kita membutuhkan keterampilan ini dalam kehidupan sehari-hari, seperti untuk membaca jam, membeli barang mainan, menghitung skor saat bermain game dan sebagainya. Pendidik perlu menjadi contoh bagi anak pribadi yang menyukai kegiatan berhitung. ${ }^{18}$

Dari berbagai paparan para ahli di atas, maka dapat disimpulkan bahwa membaca, menulis dan berhitung (CALISTUNG) merupakan materi pembelajaran sangat penting yang

\footnotetext{
16 UU Sisdiknas No. 20 Tahun 2003

17 SoegengSantoso, Pendidikan Anak Usia Dini. (Jakarta: Citra Pendidikan Indonesia, 2004), hal. 69.

${ }^{18}$ Ade Dwi Utami, dkk, Modul Pendidikan dan Latihan Profesi Guru Taman Kanak-Kanak. (Jakarta: BPSDMPK-PMP Kementrian Pendidikan dan Kebudayaan, 2013), hlm. 422-423
}

harus dimiliki anak usia 4-6 tahun untuk meningkatkan literasi dan sebagai bekal dalam melanjutkan ke jenjang pendidikan selanjutnya yaitu sekolah dasar.

\section{METODE PELAKSANAAN}

Metode pelaksanaan kegiatan ini adalah pelatihan intensif pada guru TK di kecamatan Cinere dan Limo, Depok yaitu membuat bahan ajar anak usia 4- 6 tahun dengan materi Calistung dan unjuk kerja hasil pembuatan Lembar Kerja Anak berupa buku Calistung di akhir pelatihan.

Secara umum langkah-langkah kegiatan abdimas ini bisa dibagi empat: analisa masalah dan kebutuhan, pelaksanaan dan evaluasi.

a. Melakukan studi pustaka tentang cara membuat bahan ajar dengan materi Calistung bagi para guru TK sekecamatan Cinere dan Limo.

b. Melakukan persiapan alat untuk pelatihan cara membuat bahan ajar Calistung.

c. Menentukan waktu pelaksanaan dan lamanya kegiatan pengabdian bersamasama tim pelaksana.

d. Menentukan dan mempersiapkan materi Calistung yang akan disampaikan dalam kegiatan pengabdian masyarakat.

\section{HASIL DAN PEMBAHASAN}

Setelah praktik pelaksanaan pembuatan bahan ajar LKS Calistung, maka hasil dan pembahasannya adalah:

(a) Kelompok guru (10 orang) yang membuat LKS Membaca mulai memahami bagaimana karakter bahan ajar (LKS) antara lain LKS harus variatif, mendalam, menarik, mudah, sesuai minat dan kebutuhan anak, dan sebagainya, sehingga masih diperlukan revisi kembali

(b) Kelompok guru (10 orang) yang membuat LKS Menulis, sudah cukup memahami terlihat dari cara mereka tentang menulis seperti tahapan awal menulis yakni menebalkan garis horizontal, menebalkan garis vertikal, menebalkan garis putus-putus, menulis angka dengan menebalkan garis putusputus, menulis huruf dengan menebalkan garis putus-putus, sampai menulis huruf tegak bersambung dengan 
Ana Widyastuti. et al. Peningkatan Literasi Anak Usia 4-6 Tahun Melalui Bahan Ajar Membaca, Menulis, dan ...

menebalkan huruf-hurufnya.

(c) Kelompok guru (10 orang) yang membuat LKS Berhitung. Adapun Berhitung yang prosesnya harus melalui tiga tahapan cukup terampilyaitu penguasaan konsep, masa transisi, dan lambang. Namun dalam Prinsip yang harus diperhatikan dalam berhitung ialah permainan berhitung diberikan secara bertahap, diawali dengan (1) menghitung benda-benda atau peristiwa pengalaman konkrit yang dialami melalui pengamatan terhadap alam sekitarnya, (2) Pengetahuan dan keterampilan pada permainan berhitung diberikan secara bertahap menurut tingkat kesukarannya, misalnya dari konkrit ke abstrak, mudah ke sukar, dan dari sederhana ke yang lebih kompleks, (3) Permainan berhitung akan berhasil jika anak-anak diberi kesempatan berpartisipasi dan dirangsang untuk menyelesaikan masalah-masalahnya sendiri,

Permainan berhitung membutuhkan suasana yang menyenangkan dan rasa aman serta kebebasan bagi anak. Untuk itu diperlukan alat peraga/media yang sesuai dengan benda sebenarnya (tiruan), menarik dan bervariasi, mudah digunakan dan tidak membahayakan, (5) Bahasa yang digunakan dalam pengenalan konsep berhitung seyogyanya bahasa yang sederhana dan jika memungkinkan mengambil contoh yang terdapat di lingkungan sekitar anak, (6) Dalam permainan berhitung anak dapat dikelompokkan sesuai tahap penguasaannya yaitu tahap konsep, masa transisi dan lambang, terkadang masih mengacak, namun mulai sesuai urutan yang benar.

\section{KESIMPULAN DAN SARAN}

\section{Kesimpulan}

Dengan kegiatan Pengabdian Masyarakat (Abdimas) ini, guru-guru Taman KanakKanak (TK) di kecamatan Cinere dan Limo, kota Depok ini dibina agar:

1. Mampu membuat sendiri bahan ajar Calistung ini dengan kreatif dan variatif.

2. Mampu membuat bahas ajar berupa Lembar Kerja Siswa, calistung dengan materi yang sesuai dengan usia dan tahapan perkembangan anak.

3. Mampu membuat bahan ajar berupa Lembar Kerja Siswa calistung yang berurutan dari yang paling mudah sampai yang tersulit sesuai dengan usia anak.

4. Mampu memvariasikan metode pembelajaran dalam mengajarkan calistung pada anak

\section{Saran}

Pelaksana Pengabdian Masyarakat telah mengevalusai kegiatan ini. Saran- saran yang membangun antara lain adalah:

1. Kemampuan guru TK dalam membuat bahan ajar Lembar Kerja Siswa ini harus terus dilatih supaya lebih bervariatif lagi.

2. Guru-guru TKkhususnya di kecamatan Cinere dan Limo Depok harus terus meningkatkan Literasi dengan mengasah kemampuan menulis dalam membuat LKS Calistung yang dapat diaplikasikan dalam pembelajaran di kelas.

3. Guna mengoptimalkan literasi anak, diharapkan guru-guru TK lebih sering membaca. sehingga dengan wawasan dan pengetahuan mereka dapat membuat LKS yang lebih berkualitas.

4. Guru-guru Taman Kanak-kanak (TK) di kecamatan Cinere dan Limo Depok hendaknya dapat memvariasaikan metode dan kiat supaya anak tertarik dengan pembelajaran Calistung ini, sehingga kemampuan Calistung dapat berkembang lebih optimal.

\section{DAFTAR PUSTAKA}

BSNP. (2006). Naskah Akademik Instrumen Penilaian Buku Teks Pelajaran Pendidikan Dasar dan Menengah Tahap II. Jakarta: BSNP.

Dick Walter, Carey Lou., and Carey, J.O. (2009). The Systematic Design of Instruction. Upper Saddler River, New Jersey: Pearson Education, Inc.

Direktorat Pembinaan Sekolah Menengah Atas. (2008). Panduan Pengembangan 
Ana Widyastuti. et al. Peningkatan Literasi Anak Usia 4-6 Tahun Melalui Bahan Ajar Membaca, Menulis, dan ...

Bahan Ajar. Jakarta: Departemen Pendidikan Nasional.

Dwi, Ade Utami, dkk. 2013. Modul Pendidikan dan Latihan Profesi Guru Taman Kanak-Kanak. Jakarta: BPSDMK-PMP.

Kern, Richard. (2000). Literacy and Language Teaching. Oxford: Oxford University Press.

Koesnandar. (2008). Pengembangan Bahan Ajar Berbasis Web. [Online] tersedia di http://www.teknologipendidikan .net diakses tanggal 24 September 2017.

Lestari, Ika. (2013). Pengembangan Bahan Ajar Berbasis Kompetensi. Padang: Akademia Permata

M Atwi Suparman. (2012). Panduan Para Pengajar dan Inovator Pendidikan: Desain Instruksional Modern. Jakarta: Erlangga.

Mulyasa. (2006). Kurikulum Berbasis Kompetensi. Bandung: PT Remaja Rosdakarya.

Marhnis Yamin. 2009. Kiat Pembelajaran Siswa. Jakarta: Putra Grafika.

MortimerJ.AdlerdanCharles VanDoren, ,(Ed.), "IrenePontohdkk. 2007. How

ToRedABookCaraJituMencapaiTujuanM embaca:

Indonesia:PTIndonesiaPublishing

Nurani Sujiono, Yuliani. 2009. Konsep Dasar Pendidikan Anak Usia Dini. Jakarta: PT Indeks.

Qonita, Alya. 2009.Kamus Bahasa Indonesia untuk Pendidikan Dasar. Jakarta:PT Indah Jaya Adipratama

Tim Redaksi. 2011. Kamus Bahasa Indonesia untuk Pelajar. Jakarta: Kepala Badan Pengembangan dan Pembinaan Bahasa.

UU Sisdiknas No. 20 Tahun 2003

Nasution, Laila Hadri. (2013). Analisis Literasi Informasi Pengguna Perpustakaan Universitas Sumatera
Utara. (Tesis). Bogor: Institut Pertanian Bogor.

Santoso, Soegeng. 2004. Pendidikan Anak Usia Dini. Jakarta: Citra Pendidikan Indonesia.

Susanto, Ahmad. 2017. Bimbingan dan Konseling di Taman Kanak-Kanak. Jakarta: Kencana 